\title{
Francisco Morato - Jurista e Professor $\left.{ }^{(}\right)$
}

\section{Benedicto de Siqueira Ferreira}

Ainda pelas Arcadas reboam os écos da aula inaugural dos cursos juridicos deste ano da graça de 1948!

E' a voz de um grande Mestre, de um jurisconsulto de escól que se faz ouvir, ornando a exatidão dos conceitos, a aridez do tema cientifico com o brilho de sua inteligencia peregrina, o fulgor de sua cultura incomum, os enfeites da mais castiça vernaculidade.

Desdenhosa de notas ou apontamentos, com a fluencia que a sinceridade e o entusiasmo comunicam á oração, em estilo elegante, a eloquencia moça, a figura erecta e varonil desse homem quase octogenário evocava então a "velhice verde de um Deus", tal como a cantou o Poeta.

Era mais um hino á Deusa que preside os destinos deste Templo que daqui se elevava, entoado pelo mais genuino levita do Direito, pelo mais puro liturgista da linguagem.

Ao ouvi-lo, enlevados, longe estavamos de imaginar que tão logo se cobriria a Academia de luto, que neste mesmo ano de 1948, que ainda não findou, nesta mesma sala se congregariam os Professores da Faculdade de Direito de São Paulo para prantear-lhe a morte e pranteá-la pela palavra de quem como unico titulo apresenta a honra de o ter sucedido na cátedra, sem almejar sequer a substitui-lo.

Aqui estamos, siderados ainda pela feresa do golpe que nos atingiu: sua familia, seus amigos, seus colegas, seus

(*) Discurso proferido, em nome da Congregação, na Sala João Mendes, no trigésimo dia do falecimento do saudoso Mestre. 
discipulos, entre os quais me inscrevo e de ha muito figuro, para chorar-lhe a morte, rememorar-lhe as virtudes e cultuar-lhe a memória.

Francisco Morato, porém, é Mestre que não devemos chorar com a lagrima que nos olhos baila efemera, mas com a saudade que, imorredoura, se aninha no coração.

Não vamos, lacrimosos, pranteá-lo mas haurir ânimo e coragem nos exemplos que nos legou como jurista insigne, notabilissimo Mestre de Direito, provecto advogado, sincéro patrióta e carater sem jaça.

Jurista, ele o foi por vocação: é mesmo com este arnez que inicia seu sacerdócio.

Bem revestido acudiu á liça dos torneios judiciários pois como adverte D'Aguesseau na primeira de suas dezenove "mercuriales": "le plus precieux et le plus rare de tous les biens est l'amour de son etat".

Esse amor á sua profissão de que derivam "a perseverança, que é a garantia do sucesso, o ardor no trabalho que do mesmo é condição essencial, o respeito pela profissão necessario á dignidade da vida, enfim a fé e a esperança indestrutiveis, preciósos refugios contra as decepções profissionais", esse amor á profissão o possuia no mais alto grau Francisco Morato.

"Nos dias felizes - confessou o Mestre, ao lhe ser conferido o titulo que tanto presou de professor emérito desta Faculdade - nos dias felizes que decorreram entre a infancia e a adolescencia, quando só me trabalhavam a inteligencia e o coração, ainda virgens de influencias caducas, o amor da familia purificado na alegria de meus pais, o amor de Deus sob cujo sopro tive o primeiro despertar na vida, e o amor da Patria, que venerava como uma projeção do próprio Criador; n'aqueles dias felizes, quando vinha á lanço fazer quiméras e fantasias, eu já imaginava que era no fadário das letras que me seria possivel honrar com n nome a prosápia d'aqueles que tão carinhosamente mº 
haviam dado! Passei pelas humanidades, esquadrinhei-lhe varios departamentos e me fiz jurista".

Eis a profissão de fé do Mestre insigne, eis porque a esse nobre oficio "se dedica apaixonado e resoluto mal recebe o pergaminho de bacharel" que "um dia o haveria de trazer á culminancia nesta Matriz da intelectualidade brasileira".

Feliz só poderia ter sido a escolha pois a mais ninguem, com os dotes de espirito que possuia, a grandeza d'alma que o distinguia, assentaria melhór o papel de jurista, de cujo oficio diz Appleton: "Não ha outro no qual se possa prestar a outrem tão assinalados serviços: quantas vezes não deve um cliente a seu advogado a fortuna, a honra, a reputação, a vida? e estes serviços são prestados da maneira mais nobre: com auxilio da palavra e da pena. A cada instante o advogado recebe provas de suprema confianca; é o depositário dos mais intimos segredos; os mais importantes interesses lhe são confiados. Para bem desempenhar sua missão o advogado deve possuir vasta cultura, sendo necessário que a aumente dia a dia, sem cessar"

Em bem alta conta a devemos ter, asseveram os doutos, pois para a amar é preciso respeitá-la.

E, Francisco Morato possuia ainda esta virtude: em elevadissimo conceito tinha a profissão.

Em conferencia que realizou no Instituto dos Advogados do Paraná assim realçou "O papel do jurista":

“Na verdade o oficio do jurista, proclamou, é dos mais intrincados e dignificantes na nomenclatura e hierarquia das profissões liberais, tanto pelos predicados que exige de aptidões literarias, acuidade de inteligencia, dotes de espirito, variedade de conhecimentos, visão onimoda das cousas, quanto pela função capital e sintética de distinguir o justo do injusto, de concretisar o Direito, aquilo que é a primeira e mais impreterivel condição de existencia organizada, a propria medula da vida coletiva e indivisivel, 
fundo e substancia de todas relações no trato dos homens, das familias, das sociedades e das nações.

Das dificuldades e relevancias da profissão resulta a estima e primado dos profissionais.

Em que pese aos que tocados de inveja, rivalidade ou inconsciencia, murmuram contra o que pejorativamente denominam a turba dos bachareis, certo é que aqueles que com preparo, vocacão e treino se dedicam á tarefa de defender o organismo juridico social, adquirem uma pericia e superioridade que refogem ao comum dos homens, na elaboração e inteligência das leis, no tráfico e recontros da vida civil, no tratamento e meneio dos negocios publicos".

Mas colocando a profissão bem alto, como um ideal, não impava de orgulho pessoal:

"Não vai nisto, advertia, nenhum lanço de orgulho ou jactancia. Não ha clamar contra os protagonistas da jurisprudencia nem vituperá-los de se arrogarem vaidosamente da preeminencia entre os que exercitam na vasta e luminósa esfera da intelectualidade. Sua profissão não é previlégio de ninguem: está aberta a quantos para ela tiverem pendor e coragem. $O$ que não pode ser é que pretenda operar com destreza e solércia de profissional quem para a profissão nunca teve inclinação nem preparo".

$\mathrm{E}$, na verdade, a vocação, o amor ao oficio, a lucidez da inteligencia e a opulencia da cultura são as armas que deve possuir o jurista para vencer como venceu o prof. Francisco Morato que entre Piracicaba onde começou a terçar armas nos embates no fôro, como promotor publico, e a Capital onde mais tarde alicerçou solidamente seu invejavel escritorio de advocacia, percorreu com galhardia as três idades do advogado a que se refere Bonner, evocando afinal "o magnifico espetáculo de jurisconsulto famoso, rodeado de clientes cheios de confiança que o fazem depositario de seus anceios, de suas pretensões, de seu direito. Incertos se devem penetrar no Templo da Justiça e provocar seus julgamentos, desejam se assegurar 
prèviamente se serão a seu favor as decisões. Vêm àquele que uma longa experiencia habituou a prever, implorar sua opinião e submeter suas questões a seu exame. Suas palavras irão apaziguar sua alma, dissipar as incertezas da esperança e as perturbações da consciencia. Antes de ingressar nas perigosas vias judiciais, uma voz autorizada vai the indicar o caminho, fazer-lhe conhecer os meandros, desvendar-lhe o que irá acontecer afinal".

Sáboreou assim o professor MoRato as três grandes satisfações profissionais com que acena Felix Liouville: "le plaisir de concilier, le plaisir de plaider, le plaisir de gagner son procès"

Acrescentemos porém em relação ao Mestre, com Appleton, "le plaisir de reussir, la plus grande et la plus legitime joie pour l'avocat."

Bem a mereceu pois dele se pode dizer:

"Natura incipit, scientia dirigith, ars perficit"

Venceu e venceu pela palavra e pela pena.

Pela pena - com esta linguagem "ad occulos" - em seus articulados e razões como advogado, pareceres e artigos de doutrina, como jurista, outras tantas lições de Direito a enriquecerem nossa literatura juridica.

Pela palavra, com a eloquencia que "não é só produção do espirito mas obra do coração" e que ele tão bem sabia imprimir a seus discursos, suas conferencias, suas preleções. .

Mas aqui ou acolá, orando ou escrevendo, sempre seu civismo, o mais ardente, se manifestou pelo seu amor á linguagem, esta irmã gemea do direito, imprimindo profundos laivos de vernaculidade em suas produções.

"Floresça, fale, cante, ouça-se e viva

A portuguesa lingua",

pareciam murmurar seus discursos que em "suas filigranas e arrendados de fino lavor" revelavam as noites bran- 
cas de vigilia que consagrava aos classicos, áqueles que, como diz o Visconde de Castilho, são os "abalisados pela excelencia da linguagem, altura das ideias e primor do estilo"

A jurista deste tomo, purista de tal realce, trilhando a jornada gloriosa do cultor do Direito, é bem de ver que havia de seduzir uma das catedras da Faculdade de Direito de São Paulo, se mais seduzida e honrada esta não se sentia em acolhe-lo.

Escolheu a de Direito Judiciario Civil em que no seu dizer que é o nosso, pompearam "os mais eximios jurisconsultos, dos de maiór relevo entre as lampadas da Escola: Ramalho, o sábio sistematisador da Praxe Brasileira; JoÃo MonteIro, cujo verbo elegante e fecundo ainda tange na memoria de seus discipulos; João Mendes Junior, o mais filosofo e seguro dos nossos processualistas; Estevão DE Almeida, uma das mais solertes e brilhantes cerebrações juridicas do nosso meio".

Conquista-a em brilhante concurso, tornando este Mestre de Direito e de vernaculidade ainda mais pesada a herança que hoje me recai sobre os hombros.

E, nesta "Matriz da intelectualidade brasileira", como a denominava, galgou todos os degraus na escadaria das honras, respeitado pelos colegas, venerado pelos discipulos.

Aposentado compulsóriamente, permaneceu na Direioria da Faculdade onde o alcancei sempre empenhado em The dar brilho e realce que mais que a de outrem sua permanencia, á mesma conferia, em dirigi-la com a costumeira proficiencia, em assumir desassombradamente responsabilidades, em cativar a todos com gentilezas e lhanesa do trato.

E' seu primeiro professor emerito, titulo que tanto mereceu como dele se ufanou em carinhosa demonstração de apreço á Escola, recebendo-o como "a mais excelsa, a mais conspicua, a mais dignificante, a mais cobiçada das honras que facultam as leis da Escola e só de se deferir 
ios professores catedraticos, resignatários ou jubilados, cujos serviços no magistério hajam sido reputados de excepcional relevancia!"

Mas ainda que entenda que a "supina distinção é honra que em sua munificencia o prosta nos recessos da alma quando considéra ser o numero um no tempo e na ordem da galeria desses graduados, é o premio que corôa sua jubilação oficial na catedra" não se esquece, em dignificante exemplo de amor ao trabalho, quem já era credor de "otium cum dignitate", de reivindicar o direito que o titulo outorga de "prosseguir no magistério de cursos livres, de comparecer ás reuniões de Congregação e de colaborar nas comissões universitárias".

A acariciar seus sonhos, a fruir o encanto das letras e o respeito de seus concidadãos permaneceu até o colher a morte.

Atestam-no a permanencia na Secretaria dos Negocios da Justiça, em momento crucial para São Paulo daquele que em 1930 se furtára á governança do Estado; a magnificência de sua aula inaugural de que há pouco ainda fomos testemunhas, a tese de Direito "até certo ponto verdadeiramente revolucionaria mas digna de meditação e estudo" sobre "A liberalidade simultanea de usufruto e nua propriedade inalienavel" com que brindou em marco ultimo a Revista da Ordem dos Advogados, como remate á sua produção juridica que, vasta mas esparsa, está a requerer Coletanea que a reuna e onde se engastem como joias "A Carta Testemunhavel" e "A Prescrição das Ações Divisórias", a ganhar esta fóros de legitimidade entre os classicos de nossas letras juridicas.

Advogado, jurisconsulto, mestre de direito, só então, e nisto vai mais um exemplo, sente forças para aceitar a mais bela das causas, a causa publica.

Só então ascende á tribuna parlamentar que "ofre", no dizer de Dupin, "une cause de plus a defendre et la plus belle: celle du pays", sem despir entretanto esta tunica 
que é o enlevo de sua alma, a toga do jurista que sempre lhe plasmou a personalidade inconfundivel.

Para lá, para o Parlamento Nacional o conduziu o Partido Democratico de que forra fundador e, sucedendo ao Conselheiro Antonio Prado, seu presidente e onde sua atuação foi das mais proficuas nos memoraveis prélios que constituem brilhante pagina da vida Nacional e nos quais se continuava a ação da Liga Nacionalista que tambem tanto deveu ao ilustre extinto.

Na Camara Federal, a opulencia do seu saber, sua fulgurante inteligencia, seu sadio patriotismo fazem-no desde logo respeitado e o consagram como credor da admiração de seus pares e de seus compatriotas.

Traça o arcabouço da Aliança Liberal destinada a refundir nossos costumes politicos, a lutar pelos principios democraticos, ainda que com sangue deva ser regada a arvore da liberdade.

Desvirtuada a revolução de 1930 quanto ás suas finalidades, foi um dos que semeou a ideia de congregar todos os paulistas, empenhado nessa campanha que é uma verdadeira epopéia bandeirante, de reconduzir o país ao regime Constitucional.

Nos pródromos da revolução paulista, com a amarga experiencia da rebelião de 1930 , tudo fez até a ùltima hora para a evitar, mas deflagrado o movimento, imediatamente ao mesmo se incorpora, para, afinal, derrotado este nosso São Paulo, pleitear como uma graça "a de fazerem recair sobre sua pessôa, somente sobre sua pessôa, toda a responsabilidade pelo movimento de que participou".

Em toda sua grandeza, como homem e como jurista, se impõe á admiração de seus coevos esse ente eleito que, vencido mas não convencido, preso mas com a alma livre, na Casa de Detenção do Rio de Janeiro, assume a sua e a alheia responsabilidade ao afirmar que "a maiór ofensa e maiór ultraje que eu poderia sofrer em vida, seria o de me suporem capaz de sair da linha de compostura e altivez 
nos sofrimentos, de faltar á solidariedade para com os meus companheiros e conterraneos, de esconder o devotamento infinito ao meu Estado e de procurar atenuar a minha responsabilidade nas horas aflitivas, em que São Paulo, solitário e desamparado nos sonhos de um grande idealismo, estremece na amargura da propria grandeza".

Pagina que, em seu estoicismo devera se perpetuar em bronze pois há muito está gravada no coração dos paulistas!

E' este vulto, grande como homem, que se avantajou no trato das letras juridicas e se agigantou no amor á Patria que a morte vem de prostrar!

$\mathrm{Na}$ verdade a ninguem Ela poupa.

"Mas nesta mesma igualdade, comete grande desigualdade. Matar a todos sem perdoar a ninguem, igualdade é mas deixar os que são embaraço do mundo e levar os que eram ornato dele: que desigualdade maiór".

Mas se a Morte, com esta igualdade tão desigual, como já assinalava ViEıra, com esta justiça injusta, não poupa sequer os grandes homens não tem Ela, senhores, o poder de afastar de nosso convívio um grande mestre, de ofuscar-lhe a grandeza d'alma, destruir-lhe o espirito, apagarIhe as lições, aniquilar-lhe os exemplos:

"Mortuus est Magister sed nobiscum permanet". 